\title{
IMPROVING STUDENTS' SPEAKING MOTIVATION USING MINGLE MUSIC TECHNIQUE
}

\author{
Ilinawati, Sijono \\ STKIP Persada Khatulistiwa \\ Ilina_selvin@yahoo.com,Sijonostg4@gmail.com
}

Submitted : 2019-12-05

Accepted : 2020-04-11

\begin{abstract}
This study is about improving students' speaking motivation using mingle music technique. The data were taken from the students of English Language Study program of STKIP Persada Khatulistiwa Sintang, in Academic Year 2018/2019. A classroom action research was conducted in this study. To collect the data, the researchers used observation checklist, field notes, and interview. The research was done in two cycles, where one meeting in each cycle. The result showed that the students' motivation in teaching learning process improved from each cycles. Mingle music technique involved the students to be more active and energetic in the classroom. It enable the students to have more practices and experiences in speaking with different students and material. As the conclusion, the implementation og Mingle music technique succeeded improving students' speaking motivation.
\end{abstract}

Keywords: Mingle Music Technique, Students' Speaking Ability.

\section{INTRODUCTION}

One of the goals in learning English is being able to communicate. In communicating with other people, we do not only need the ability to speak, but we need the motivation to do it. Speaking is a process of conveying ideas and opinions as well as information to others through language. In students' perspective, speaking is difficult and complicated subjects in learning English. It is indicated with the difficulty in communicating and understanding the meaning. Teaching and learning to speak must be focused at helping students to be encourage to communicate in English in the context of real life. Speaking does not only concern on delivering ideas, but also producing good sound, constructing the sentences, and generating the ideas. Therefore, in English learning is expected to be able to provide active speaking experiences and motivation for students. Thus, the students can use English not only to improve their knowledge but also to add their experiences.

The researchers investigated that the students experienced many difficulties in speaking such as the students were passive in responding the questions from the lecturer, afraid of making mistakes, and lack of motivation. Therefore, in order to help them, the teacher applied mingle music technique to enable the students to motivate in speaking. This technique involves the students to have more practices and experiences in speaking English with their friends by using mingle music. By listening to the music the students 
would not feel ashamed and force be free to speak, because they can speak freely, without any pressure. The use of appropriate music becomes supporting factors to arise the students' attention and bravery to speak.

\section{LITERATURE REVIEW}

\section{Defining Motivation}

Motivation is very important for students who are learning. By having motivation the students can engage actively to all learning activities. Crookes \& Schimts cited in Norris ( 2001 ) mentioned that motivation recognized as students' directive to the goal of second language learning. In line with the idea, Brown ( 2000 ) explains that motivation could be the most frequently used cath- all terms for describing the real success or failure of basically any complex assignment. So, it could be assumed that someone can succeed because of she/he felt motivated. Meanwhile, Moore ( 2005 ) argues that motivation could be described as something energizes, and guides our attitude. So motivated behavior is energized, directed and sustained behavior.

\section{Teaching Speaking}

What is speaking ? in line with this question, some experts proposed the definition of speaking as follow. Speaking is an activity to deliver the information through words or sentences. Some experts proposed the definition of speaking. Speaking is as a kind of conveying the information through words or sentences. Speaking is also a part of daily life activity that one get it for granted. The average person results tens of thousand of words a day ( Thornbury, 2007,P.1). In line with that, Harmer ( 2007 ) there are three main reasons for getting students to be able in the classroom. Firstly, speaking activities give rehearsal opportunities to practice real - life speaking in the classroom. Secondly, speaking tasks provide students to use any or all of the language the know and give the feedback for teacher ans students. In addition, He \& Chen ( 2010 ) mentioned that student's self evaluation for their speaking ability as imperfect leads to insecurity about communicating with others.

\section{Aspect of Speaking Skill}

There are some aspects of speaking which focused in this research. Those aspects are pronunciation, vocabulary, fluency, comprehension, and grammatical accuracy.

\section{a. Pronunciation}

Rai (2010, p. 27)explains that pronunciation is the accepted standard of the way in which the words are produced; correct and clear is priority and indicates that the speakers are careful and focus on audiences' attention and reaction. Nation and Newton (2009, p. 75 
)state that a normal communication, and particularly intelligibility could occur because of having a good pronunciation of the language.

\section{b. Vocabulary}

According to Rai ( 2010, p.112 ) states that vocabulary is word list, in alphabetical order.

Rai (2010, p. 112)explains that vocabulary is words list, usually given in alphabetical order. Vocabulary also means the stock of words used by a person. It was possible to make specialized vocabularies which give good coverage for certain kinds of text.

\section{Fluency}

According to Fulcher\& Davidson (2007, p. 7) in order to measure 'fluency' we have to state what we could possibly observe in speech to make a decision about whether a speaker is fluent. Fluency is provided by producing interesting classroom activities in which students have to generate the idea, negotiate meaning, use communications tricks, appropriate understanding and keep going the conversation.

\section{d. Comprehension}

Nunan $(2004$, p. 79$)$ mentions that comprehension comes from the context in which the language occurs as well as from extra-linguistic information.

\section{e. Grammatical Accuracy}

Accuracy means that the speakers are able to combine the vocabulary, grammar and pronunciation in appropriate order and function. For accuracy, the attention is at the ratio of correct to incorrect tense use or word order (Fulcher \& Davidson, 2007, p. 8).

\section{Mingle Music Technique}

A mingle is an speaking activity where involved the students to talk with friends by approaching and moving to one and another classmates ( Borzova : 2014 ). There are some steps of applying mingle model. First, the students are walking around and talking freely with other students. The activity can be applied in the form of rotating pairs in circle. Where the students from inner and outer circle face each others. The students from both circles will find new friend to speak after moving one step ( or one seat ) clockwise. The rotating-pair mingle typically requires more organization. To make the activity more fun, the researchers used music. The use of music is intended to give a variety to the technique. Music is containing authentic side, informal language that is normal to the ear. Songs provides precious resources that increase students' abilities in listening, speaking, reading and writing ( Saricoban et al., 2000). By having music the students would feel free to speak without any burdens and pressure. The use of appropriate music becomes supporting factors to arise the students' attention and bravery to speak.

\section{METHOD}


The method is used to describe the theory of how investigation should precede that engages analysis of the principles and mechanism in a particular field of investigation, Schwandt cited in deMarrais and Lapan (2004,p.5 ). Referring to the problem found, the most appropriate method to be used is classroom action research. In this research, the researchers applied two cycles, which consisted of one meeting for each cycles. Classroom action research usually directs on finding the solution the problem found in classroom management, instructional strategies, the use of material or student learning behavior. Burn cited in Richards and Farrel ( 2005,p.11) states that professional improvement activity such as action research that are " fused into school or organizational change become an important way of facilitating school curriculum renewal and assuring that language teachers maintain greater ownership of curriculum implementation."

The research applied mingles music technique to improve students' speaking motivation. The technique of data collection were observation technique and interview. The observation techniques done through observation sheet. To collect the data the researchers used the following instruments: ( 1) Observation Sheet; (2) Field Notes; (3 ) Interviews.

The researchers conducted the reconnaissance step to discover information related to the students' problems. When the problems was found, after that the researchers tried to identify the most feasible problems to be solved, then the researchers made plans to choose the actions that could be conducted in the field. In planning phase, the researchers work together with the collaborator in making set of lesson, discussing about the topic and selecting an attractive music which applied in mingle activity. The researchers and the collaborator then discussed the possibility and the scale of priorities of the implementation. After the planning approved, the actions implemented in the class. The action was carry out in two cycles.

The researchers observed the students' reaction in the actions. After that the researchers talked over with the collaborator about the influences of the execution of the actions to be evaluated in the next cycle. The result of this evaluation process was considered for the reflection in the next step. The reflection done after one cycle of the research finished. The researcher and the collaborator discussed the circumstances concerning the actions. It done to discover whether, the action was successful or not. If the action carried out was successful, the researcher would keep carrying out. In the other hand, if the action is not successful, the researchers would try to figure out the suitable action to assist the students to improve their speaking motivation in the next meeting of each cycle. 


\section{FINDING AND DISCUSSION}

\section{Cycle 1}

1. Students' Involvement during the activity

To recognize the students' engagement during the teaching learning process, the researchers used two instruments. The instruments were observation sheets and field note. The students' involvement was analyzed through observation sheets, while the lecturer's performances were recorded in the field note. The other aspects that were not covered in the observation sheets were also recorded in field note. The data that recognize from the observation sheet was the students' involvement during the teaching learning process using mingles music technique. The topic in cycle 1 was Daily Routine.

The observer scored the students' involvement reffered to the number of students involved in learning activity. If $17-22$ students do the activities the score is 4 , which is considered in very good category. If $12-16$ students do the activities the score is 3 or good category. If there are $7-11$ involve in the activities the score is 2 which is considered Fair. Score 1 is given if there are about $3-6$ students who involve in the activity. Last category is very poor, means there is no student who involve in the activity. The score for this category is 0 .

In general, the percentage of students' involvement was obtained from the total score got from the observation sheets was 45 divided by maximum total score 56 then multiplied $100 \%$. As a result the percentage of the students' involvement during the teaching learning activities by using mingle music technique was $80.36 \%$. It means that more students involved in the activities.

There were 14 items to be observed in the observation sheet. Even though each item in the observation sheets got good score, but there were two items that required to be enhanced. The data obtained from observation sheet shown, there were $7-11$ students were not active in the activities, they tended to be passive when the lecturer asked them to practice the mingle music and also involved in mingle music activities. Based on field note, almost students were passionate in following the teaching learning activity, but some students were still not assured with their activities.

2. The students' Motivation in speaking

Table 2.Students' Motivation

\begin{tabular}{|l|l|l|}
\hline No & The indicator of Motivation & Category \\
\hline 1 & $\begin{array}{l}\text { The increasing of students' attitude toward the } \\
\text { technique }\end{array}$ & good \\
\hline 2 & Students' confidence in speaking & fair \\
\hline 3 & Students' participation in learning process & good \\
\hline
\end{tabular}




\begin{tabular}{|l|l|l|}
\hline 4 & Students' achievement & good \\
\hline
\end{tabular}

Table 2. Criteria of Success of the cycle

\begin{tabular}{|l|l|c|}
\hline No & The Criteria of Success & Instruments \\
\hline 1 & $\begin{array}{l}\text { At least } 80 \% \text { students respond positively and } \\
\text { are actively involved in the teaching learning } \\
\text { process using mingle music technique. }\end{array}$ & Observation sheet, field note \\
\hline 2 & $\begin{array}{l}\text { At least } 80 \text { students } \\
\text { werevigorouslyinvolvedin learning activity } \\
\text { by using mingle music technique. }\end{array}$ & Interview \\
\hline
\end{tabular}

To conclude, findings in cycle 1 had already met the criteria of success( see table 2 ). Those were proven from the result of observation sheets reached 80,36 \%. It indicates that the students were really actively involved in learning process by using mingle music technique.. The data from field note and interview also show that the students positively engaged in the activity. Even though the findings of the research had already met the criteria of success but the researchers decided to take another cycle to make sure that the technique could be implemented for other materials or topics. In additional, the researchers wanted to give more experiences to the students to use mingle music technique.

\section{Cycle II}

1. Students' Involvement during the activity

The previous cycle already met the criteria of success, but in this case the researchers explored more the experience teaching using mingle music technique especially for speaking ability. Even though, the finding in cycle 1 already success but researchers assumed that there were still some weaknesses needed to be improved in this cycle. The researchers redesign the lesson plan based the reflection of cycle 1, including considered the strength and the weakness of the teaching learning process based on observation sheet and field note. In this cycle the researchers also change the material or topic. Besides the researchers provided more time for the students to do the interview in the mingle music activity. As the comparison in the first cycle the researchers provided 2 minutes speaking time or each student to explore their friends' information related to the topic before switching the pair. In this cycle researchers provided 3 minutes speaking time. In additional, the researchers also used more attractive music. The music used in cycle two was dangdut.

The percentage of students' involvement was increased from the previous cycle. There are 15 items to be scored in the observation sheet. $60 \%$ items got score 4 , it means very good category. The rest $40 \%$ items got score 3 categorized as good. The data shows 
that the students' involvement in this cycle was considered very good. The percentage of the students' involvement in this cycle was $90 \%$, this data shows that the students' involvement in teaching learning activity was experienced an increase compare to the previous cycle. The improvement the students' involvement towards the cycles was about $7 \%$. This number reflects that almost students actively engaged in following the learning activity by using mingle music technique. The interview also confirmed that the students were very happy engaged in the activity. The data from field note also shows that most students enthusiastically involve in mingle music technique. Besides, they were enthusiastically prepared and presented their tasks.

\section{Students 'Speaking Motivation}

The researchers applied the interview to some students to investigate the motivation towards the activities in the classroom. The question in interview consisted of four aspects, they are 1) Students' attitude towards the technique, 2) Students' confidence in speaking, 3) Students' participation in learning process, 4) students' achievement in speaking. In general the students' respond positively and were motivated in following the learning activity in he classroom. It means that the students 'speaking motivation increased from the previous cycle.

Table 3.Students' speaking motivation

\begin{tabular}{|l|l|l|}
\hline No & The indicator of Motivation & Category \\
\hline 1 & $\begin{array}{l}\text { The increasing of students' attitude toward the } \\
\text { technique }\end{array}$ & Very good \\
\hline 2 & Students' confidence in speaking & good \\
\hline 3 & Students' participation in learning process & Very good \\
\hline 4 & Students' achievement & Very good \\
\hline
\end{tabular}

The data in table 3 reflects that mingle music technique could improve students 'motivation in speaking, thus proven by the increase of students behavior in each aspect. There were two aspects that categorized as very good they were students' attitude ,students participation in the activity, and students' achievement. This was as the result of the strengthening technique given in pre-activity. Students' confidence also increased from the previous cycle. 
After the reflection of the second cycle, it could be concluded that data analyzed of all instruments met the criteria of success. Due to the findings already met the goals of this research, the researchers stopped the action because they concluded that the implementation of mingle music technique in cycle 2 was fulfilled.

\section{CONCLUSION}

This research tries to find out how the implementation of mingle music technique in improving students' speaking motivation. Based on the findings of the action research conducted in two cycles, it can be concluded that mingle music technique successfully boosted students' speaking motivation. In addition, the students' attitude, confidence, participation, and achievement improved well toward the cycle. Meanwhile, mingle music technique can increase the students' motivation in teaching - learning process. The students were more vigorously and interested in doing mingle activity. Besides, they did the tasks seriously when they presented the report in front of the class.

Hopefully, this research can give awareness and motivation about the importance of the English learning and facilitate students to boost their speaking ability. This research can be guidance for teachers who want to add the knowledge and explore the experience in improving students' speaking motivation. In addition, other researchers can use this research to conduct further research.

\section{References}

Borzoya, E.(2014). Mingles in foreign language classroom. English Teaching Forum, (2).

Brown, H. D. (2000). Principle of Language Learning and Teaching. 4th Edition. New York: Pearson Education.

Darmayenti., \& Nofiandri. N. (2015). Mingle model for teaching English speaking skill for college students. AT-TALIM 22(1), 1-9. State Institute for Islamic Studies Imam Bonjol, Padang.

deMarrais, K., \& Lapan, S. D. (2004). Foundation for Research : Methods of Inquiry in Education and Social Sciences. New Jersey: Lawrence Eribaum Associated.

D. Moore, Kenneth. (2005). Effective Instructional Strategies-From Theory to Practice California: Sage Publication, Inc.

Fulcher, G., \& Dayidson, F. (2007). Language Testing and Assessment. Oxon: Routeledge.

Harmer, J. (2007). How to Teach English, Essex: Longman. 
He, Summer x \& Chen, Amanda J. Y, (2010), How to Improve Spoken English. [Online] Available: http://sites.google.com/site/languagejournal/Home/how-to-improvespoken-English

Nation, I. S. P., \& Newton, J. (2009). Teaching ESL/EFL Listening and Speaking. New York: Routledge.

Norris, J. (2001). Motivation as A Contributing Factor in Second Language Acquisition. (On Line. Retrieved on July 2011). www.http//itesjl.org/Article/NorisMotivation.html.

Nunan, D. (2004). Task-based Language Teaching. New York: Cambridge University Press.

Rai, U. (2010). English Language Communication Skills. Mumbai: Himalaya Publishing house PVT.LTD.

Richards, J. C., \& Farrel, T. S. C. (2005). Proffesional Development for Language Teachers : Strategies for Teacher Learning. New York: Cambridge University Press.

Saricoban, A. \& Metin, E. (2000). Songs, Verse and Games for Teaching Grammar. The Internet TESL Journal, 6(10).

Thornbury, S. (2007). How to Teach Speaking. Essex: Longman. 